Jurnal Kebidanan Mutiara Mahakam, Vol 8, No 1, Tahun 2020, Hal 51-69

ISSN : 2623-2553 (Online)

ISSN : 2549-0532 (Cetak

\title{
ANALISIS FAKTOR MASALAH PERTUMBUHAN (STATUS GIZI, STUNTING) PADA ANAK USIA < 5 TAHUN DI WILAYAH KERJA PUSKESMAS SIDOMULYO KOTA PEKANBARU
}

\author{
Islah Wahyuni ${ }^{1}$ \\ ${ }^{1}$ Program Studi D-III Kebidanan Stikes Payung Negeri Pekanbaru \\ email : islah_fattan@yahoo.co.id

\begin{abstract}
Dikirim : 3 Februari 2020
Diterima : 3 Maret 2020

Diterbitkan : 20 Maret 2020
\end{abstract}

\begin{abstract}
Nutritional problems in toddlers are influenced by not enough nutritious food balanced at the age of toddlers, inadequate nutritional care and children suffer from infectious diseases, Poverty is also one of the causes of malnutrition. Early detection of growing is an activity/examination of early finding of growth irregularities in toddlers. The purpose of research to identified the growth factor: Nutrition Status, event Stunting in children aged $<5$ years in the work area Puskesmas Sidomulyo Pekanbaru. Sample amounted to 30 toddlers 12-59 months in Puskesmas Sidomulyo, with the Consencutive sampling technique. Time of research was December 2019. Research instruments: Digital weight scales, body length meters, Midline and questionnaires. Data analysis using the Rank Spearman. There is a knowledge Factor of 16 respondents (53.3\%) Less knowledgeable, the majority of maternal education is low 19 people (63.3\%), there is a history of infectious diseases of 23 people (76.7\%), and a low family income of 20 people (66.7\%) and immunizations incomplete 17 people (56.7\%). Existence of knowledge of mothers with nutritional problems (stunting) (0.00), there is a relationship factor education with the problem of nutrition (stunting) (0.00), the family income relationship with the problem of nutrition (0.001), the history of infection in children with nutritional problems (stunting) (0.00), the immunization history with with nutritional problems (stunting) (0.010). Recommended for health workers to improve the counseling to mothers about nutritional problems in toddlers.
\end{abstract}

Keywords: toddler, nutritional problem factor, Stunting 
Jurnal Kebidanan Mutiara Mahakam, Vol 8, No 1, Tahun 2020, Hal 51-69

\section{PENDAHULUAN}

Saat ini Indonesia dihadapkan pada Beban Gizi Ganda atau sering disebut Double Burden,(Kementerian Kesehatan RI, 2018) yang artinya pada saat negara ini masih terus bekerja keras mengatasi masalah Kekurangan Gizi seperti gizi buruk, kurus, dan stunting, namun pada saat yang sama juga harus menghadapi masalah kelebihan gizi atau obesitas khususnya pada balita (Sandra, Ahmad, \& Arinda, 2018).

Penilaian status gizi anak menjadi sangat penting saat ini, karena balita mengalami proses pertumbuhan dan perkembangannya sangat pesat dan mereka mebutuhkan asupan nutrisi yang baik untuk proses tersebut(Bardosono, 2016). Masalah gizi buruk dan kurang sering terjadi pada bayi dan balita $<5$ tahun akibat kelalaian dan pola asuh yang salah dari orangtua mereka(R. Handayani, 2017). Angka Kematian balita (AKABA) dipicu salah satunya dengan masalah gizi pada balita yang tidak mendapatkan penanganan yang tepat(Kementerian Kesehatan RI, 2018), akibat dari masalah gizi yang menahun pada balita(Manggala et al., 2018). Status gizi balita dinilai menurut 3 indeks : Berat Badan Menurut Umur (BB/U), Tinggi Badan Menurut Umur (TB/U), Berat Badan Menurut Tinggi Badan (BB/TB) (Kementerian Kesehatan RI, 2018).

Di Indonesia, berdasarkan Pemantauan Status Gizi (PSG) 2017 menunjukkan status gizi balita buruk $3,8 \%$, gizi kurang $14,0 \%$, gizi baik $80,4 \%$ dan gizi lebih $1,8 \%$. Sedangkan permasalahan balita yang sangat pendek sebesar 9,8\%, balita pendek sebesar 19,8\%, angka ini meningkat dari tahun 2016.

Indonesia merupakan Negara ke 5 dengan jumlah balita tertinggi mengalami stunting,(37\%) setelah Pakistan(Beal, Tumilowicz, Sutrisna, Izwardy, \& Neufeld, 2018)(Manggala et al., 2018), Balita merupakan usia emas (golden period) terutama untuk pertumbuhan janin sehingga bila terjadi gangguan pada masa ini tidak dapat dicukupi pada masa berikutnya dan akan berpengaruh negatif pada kualitas generasi penerus(Kementerian Desa Pembangunan Daerah Tertinggal dan Transmigrasi, 2017). Periode 1000 hari pertama kehidupan dimulai dari janin hingga anak berusia dua tahun(Ditjen Kesmas, 2018) serta periode yang berpotensi signifikan serta adanya kerentanan; fisik dan psikososial yang dapat berdampak besar terhadap pertumbuhan dan perkembangan anak usia dini, pertumbuhan fisik anak dapat dipengaruhi oleh kurangnya akses terhadap kebutuhan dasar serta faktor psikososial seperti depresi ibu, ekonomi dan lainnya(Smith Fawzi et al., 2019). Stunting 
Jurnal Kebidanan Mutiara Mahakam, Vol 8, No 1, Tahun 2020, Hal 51-69

(Anak kerdil) yang terjadi di Indonesia sebenarnya tidak hanya dialami oleh rumah tangga/keluarga yang miskin dan kurang mampu, karena stunting juga dialami oleh rumah tangga/keluarga yang tidak miskin/yang berada di atas $40 \%$ tingkat kesejahteraan sosial dan ekonomi(Jahari, 2018)

Stunting adalah kondisi gagal tumbuh pada anak balita (bayi di bawah lima tahun) akibat dari kekurangan gizi kronis sehingga anak terlalu pendek untuk usianya(Boucot \& Poinar Jr., 2010), Stunting merupakan suatu bentuk gizi buruk yang dicirikan dengan adanya gangguan pertumbuhan dalam dua tahun pertama kehidupan anak, berdampak pada seperempat anak secara global. Sementara status nutrisi tetap menjadi penyebab utama stunting, bahkan adanya bukti bahwa faktor lingkungan berisiko terjadinya stunting(Vilcins, Sly, \& Jagals, 2018). Stunting berdampak pada tingkat kecerdasan, kerentanan terhadap penyakit, menurunkan produktifitas dan kemudian menghambat pertumbuhan ekonomi, meningkatkan kemiskinan dan ketimpangan, Memperburuk kesenjangan/inequality, Mengurangi 10\% dari total pendapatan seumur hidup, Kemiskinan antar-generasi(Keuangan, 2018), Pertumbuhan otak anak terhambat(Jahari, 2018), Pertumbuhan fisik terhambat, rentan terhadap penyakit infeksi, daya adaptasi lingkungan rendah, dan berisiko menderita penyakit tidak menular pada usia dewasa(Kementrian Kesehatan, 2010). Faktor Prenatal memiliki peran penting dalam insiden stunting. Kegagalan pertumbuhan adalah manifestasi utama dari malnutrisi selama kehamilan dan lahir dengan berat lahir rendah(Indriani, Dewi, Murti, \& Qadrijati, 2018)

Stunting didefinisikan sebagai tinggi badan berdasarkan usia berada dibawah skor z (<-2SD), dihitung dengan mengurangi usia-dan nilai median jenis kelamin yang sesuai dari populasi standar dan membagi oleh SD dari populasi berdasarkan standar WHO(4). Standar WHO yang direkomendasikan dalam menegakkan stunting adalah Suatu keadaan balita dengan status gizi yang berdasarkan panjang atau tinggi badan menurut umur bila dibandingkan dengan standar baku WHO-MGRS (Multicentre Growth Reference Study) kurang dari -2SD(Leroy \& Frongillo, 2019).

Pentingnya pengetahuan orangtua dalam pencegahan stunting yang terjadi pada balita akan berdampak pada perubahan prilaku dan pola asuh orangtua dalam merawat balita mereka agar tidak menjadi stunting(D. S. Handayani, Sulastri, Mariha, \& Nurhaeni, 2017). Disamping itu di tingkat masyarakat, tenaga kesehatan juga harus memiliki pengetahuan 
Jurnal Kebidanan Mutiara Mahakam, Vol 8, No 1, Tahun 2020, Hal 51-69

yang baik tentang stunting dengan memberikan informasi stunting dengan benar, melakukan intervensi layanan kesehatan dengan tepat, serta membangun kepercayaan masyarakat agar akhirnya dapat terdapat perubahan perilaku pencegahan stunting yang signifikan (Ditjen Kesmas, 2018)

Berdasarkan hasil pemantauan status gizi di provinsi Riau pada tahun 2017 di Riau menunjukkan status gizi buruk 4,20\%, gizi kurang 14,00\% dan balita yang sangat pendek sebesar 11,20\% dan pedek 18,50\% (Kementerian kesehatan Repubelik Indonesia, 2018). Dan berdasarkan pemantauan status gizi tahun 2017 di Pekanbaru menunjukkan status gizi buruk $0,89 \%$, gizi kurang $8,57 \%$, gizi lebih $2 \%$ dan balita yang sangat pendek sebesar 3,83\% dan pendek sebesar $15,39 \%$. Oleh sebab itu peneliti tertarik untuk melakukan penelitian untuk melakukan penjaringan data langsung terhadap balita yang mengalami masalah gizi dan stunting dan faktor -faktor yang mempengaruhinya.

\section{METODE PENELITIAN}

Penelitian ini merupakan jenis penelitian analitik observasional dengan pendekatan cross sectional. Penelitian ini mengambil lokasi di wilayah kerja puskesmas Sidomulyo dan dilaksanakan pada bulan Desember 2019. Populasi pada penelitian ini adalah ibu-ibu yang memiliki balita $<5$ tahun yang mengalami masalah gizi dan stunting sebanyak 30 orang. Pengambilan sampel dilakukan dengan menggunakan teknik consencutive sampling. Sampel akan diambil sesuai dengan kriteria inklusi dan eksklusi yang sudah ditentukan. Kriteria inklusi : 1. Usia 12-59 bulan, 2. Mengalami masalah pertumbuhan (gizi/stunting). Kriteria eksklusi: 1. Bayi 0-11 bulan 2. Ada kecacatan fisik bawaan. Cara pengambilan data menggunakan data primer melalui pengisian kuesioner, serta status gizi responden yang diukur melalui pemeriksaan berat badan dan tinggi badan dengan menggunakan table $\mathrm{Z}$ score standar WHO. Hasil penelitian disajikan dengan menggunakan analisis univariat untuk mendeskripsikan karakteristik dan disribusi setiap variabel penelitian. Analisis bivariat dilakukkan untuk melihat hubungan antar variabel bebas dengan variabel terikat. Uji yang digunakan adalah uji Spearman Rank dengan nilai $p$-value $<0.05$. 
Jurnal Kebidanan Mutiara Mahakam, Vol 8, No 1, Tahun 2020, Hal 51-69

\section{HASIL DAN PEMBAHASAN}

Hasil penelitian yang telah dilakukan tentang "Analisis Faktor Masalah Pertumbuhan : Status Gizi, Kejadian Stunting Pada Anak Usia < 5 Tahun Di Wilayah Kerja Puskemas Sidomulyo Kota Pekanbaru Tahun 2019”, dengan jumlah responden 30 balita, diperoleh data sebagi berikut:

\section{a. Data Univariat}

Tabel 1.1 Distribusi Frekuensi Karakteristik Ibu Balita di Wilayah Kerja Puskesmas Sidomulyo Pekanbaru Tahun 2019

\begin{tabular}{|c|c|c|c|c|}
\hline No. & Uraian & Kategori & Frekuensi & Persentase (\%) \\
\hline \multirow[t]{4}{*}{1.} & Umur ibu & $<20$ tahun & 0 & 0 \\
\hline & & 20-35 tahun & 12 & 40 \\
\hline & & $>35$ tahun & 18 & 60 \\
\hline & Jumlah & & 30 & 100 \\
\hline \multirow[t]{3}{*}{2.} & Pekerjaan & Bekerja & 6 & 20 \\
\hline & & Tidak bekerja & 24 & 80 \\
\hline & Jumlah & & 30 & 100 \\
\hline
\end{tabular}

Dari tabel 1.1 berdasarkan umur, mayoritas ibu balita berada dalam umur $>35$ tahun sebanyak 18 orang $(60 \%)$ dan berdasarkan pekerjaan, mayoritas ibu tidak bekerja sebanyak 24 orang $(80 \%)$.

Table 1.2 Distribusi Frekuensi Data Balita di Wilayah Kerja Puskesmas Sidomulyo Pekanbaru Tahun 2019

\begin{tabular}{lllcc}
\hline No. & Uraian & Kategori & Frekuensi & Persentase (\%) \\
\hline 1. & Jenis kelamin & Laki-laki & 17 & 56,7 \\
& & Perempuan & 13 & 43,3 \\
& & $\mathbf{3 0}$ & $\mathbf{1 0 0}$ \\
2. Jumlah & & 11 & 36,7 \\
& Umur Balita & 12-24 bulan & 12 & 40 \\
& & 25-36 bulan & 5 & 16,7 \\
& 37-48 bulan & 2 & 6,6 \\
& & 49-59 bulan & $\mathbf{3 0}$ & $\mathbf{1 0 0}$ \\
\hline
\end{tabular}

Dari tabel 1.2 berdasarkan jenis kelamin mayoritas balita berjenis kelamin lakilaki sebanyak 17 orang $(56,7 \%)$ dan berdasarkan umur, mayoritas balita berumur antara 25-36 tahun sebanyak 12 orang (40\%). 
Jurnal Kebidanan Mutiara Mahakam, Vol 8, No 1, Tahun 2020, Hal 51-69

Tabel 1.3 Distribusi Frekuensi Klasifikasi Masalah Gizi pada Balita di Wilayah Kerja Puskesmas Sidomulyo Pekanbaru Tahun 2019

\begin{tabular}{|c|c|c|c|c|}
\hline No & Uraian & Kategori & Frekuensi & Persentase (\%) \\
\hline \multirow[t]{5}{*}{1.} & $\mathrm{BB} / \mathrm{U}$ & $\begin{array}{l}\text { BB sangat kurang } \\
\text { (severely underweight) }\end{array}$ & 8 & 26,7 \\
\hline & & BB kurang (underweight) & 19 & 63,3 \\
\hline & & Normal & & \\
\hline & & & 3 & 10 \\
\hline & Jumlah & & 30 & 100 \\
\hline \multirow[t]{4}{*}{2.} & $\mathrm{~TB} / \mathrm{U}$ & $\begin{array}{l}\text { Sangat Pendek (severely } \\
\text { stunted) }\end{array}$ & 6 & 20 \\
\hline & & Pendek (stunted) & 14 & 46,7 \\
\hline & & Normal & 10 & 33,3 \\
\hline & Jumlah & & 30 & 100 \\
\hline \multirow[t]{4}{*}{3} & $\mathrm{BB} / \mathrm{TB}$ & $\begin{array}{l}\text { Gizi Kurang (severely } \\
\text { wasted) }\end{array}$ & 10 & 33,3 \\
\hline & & Gizi Buruk (wasted) & 3 & 10 \\
\hline & & Normal & 17 & 56,7 \\
\hline & Jumlah & & 30 & 100 \\
\hline
\end{tabular}

Dari table 1.3 berdasarkan berdasarkan $\mathrm{BB} / \mathrm{U}$ mayoritas adalah $\mathrm{BB}$ kurang (underweight) 19 reponden (63,3\%). Berdasarkan TB/U mayoritas Pendek (stunteed), 14 responden (46,7\%), dan berdasarkan BB/TB mayoritas Gizi Baik (Normal) 17 responden $(56,7 \%)$.

Tabel 1.4 Distribusi Frekwensi Faktor-Faktor Masalah Gizi (Stunting) pada Balita di Wilayah Kerja Puskesmas Sidomulyo Pekanbaru Tahun 2019

\begin{tabular}{lllcc}
\hline No & Uraian & \multicolumn{1}{c}{ Kategori } & Frekuensi & Persentase (\%) \\
\hline 1 & Pengetahuan & Kurang & 16 & 53,3 \\
& & Cukup & 10 & 33,3 \\
& & Baik & 4 & 13,4 \\
& \multirow{4}{*}{ Jumlah } & & $\mathbf{3 0}$ & $\mathbf{1 0 0}$ \\
& Pendidikan & Rendah & 19 & 63,3 \\
& & Menengah & 4 & 13,4 \\
& & Tinggi & 7 & 23.3 \\
& \multirow{2}{*}{ Jumlah } & & $\mathbf{3 0}$ & $\mathbf{1 0 0}$ \\
3. & Pendapatan & Rendah & 20 & 66,7 \\
& keluarga & Tinggi & 10 & 33,3 \\
& Jumlah & & $\mathbf{3 0}$ & $\mathbf{1 0 0}$ \\
\hline
\end{tabular}


Jurnal Kebidanan Mutiara Mahakam, Vol 8, No 1, Tahun 2020, Hal 51-69

\begin{tabular}{lllcr}
\hline \multirow{4}{*}{4} & Riwayat & Ada riwayat & 23 & 76,7 \\
& infeksi & Tidak ada & 7 & 23,3 \\
& \multicolumn{1}{c}{ Jumlah } & & $\mathbf{3 0}$ & $\mathbf{1 0 0}$ \\
5 & Riwayat & Lengkap & 13 & 43,3 \\
& imunisasi & Tidak lengkap & 17 & 56,7 \\
& \multicolumn{1}{c}{ Jumlah } & & $\mathbf{3 0}$ & $\mathbf{1 0 0}$ \\
\hline
\end{tabular}

Dari table 1.4 Terdapat Factor yang mempengaruhi masalah status gizi (stunting) pada anak, dari aspek pengetahuan didapatkan hasil 16 responden (53,3\%) berpengetahuan kurang, mayoritas pendidikan ibu Rendah (SD, SMP) sebanyak 19 orang $(63,3 \%)$, pendapatan keluarga rendah sebanyak 20 orang $(66,7 \%)$ dan ada riwayat infeksi penyakit sebanyak 23 orang (76,7\%), dan imunisasi yang tidak lengkap sebanyak 17 orang $(43,3 \%)$.

\section{b. Data bivariate}

Tabel 1.5

Hubungan Faktor Pengetahuan terhadap Masalah Gizi (Stunting) pada Balita di Wilayah Kerja Puskesmas Sidomulyo Pekanbaru Tahun 2019

\begin{tabular}{|c|c|c|c|c|c|c|c|}
\hline No & Uraian & \multicolumn{4}{|c|}{ Masalah gizi (stunting) } & Jumlah & P value \\
\hline & Pengetahuan & Ya & $\%$ & Tidak & $\%$ & & \\
\hline 1 & Kurang & 12 & 60 & 4 & 40 & 16 & 0,00 \\
\hline 2 & Cukup & 7 & 35 & 3 & 30 & 10 & \\
\hline 3 & Baik & 1 & 5 & 3 & 30 & 4 & \\
\hline & Jumlah & 20 & 100 & 10 & 100 & 30 & \\
\hline
\end{tabular}

Dari table 1.5 Terdapat hubungan Factor pengetahuan ibu yang mempengaruhi masalah status gizi (stunting) pada balita (0.00) $p$ value $<0,05$

Tabel 1.6 Hubungan Faktor Pendidikan terhadap Masalah Gizi (Stunting) pada Balita di Wilayah Kerja Puskesmas Sidomulyo Pekanbaru Tahun 2019

\begin{tabular}{llcccccc}
\hline No & Uraian & \multicolumn{4}{c}{ Masalah gizi (stunting) } & Jumlah & P value \\
\hline & Pendidikan & Ya & \% & Tidak & \% & & \\
\hline 1 & Rendah & 14 & 70 & 5 & 50 & 19 & 0,00 \\
\hline 2 & Menengah & 2 & 10 & 2 & 20 & 4 & \\
\hline 3 & Tinggi & 4 & 20 & 3 & 30 & 7 & \\
\hline & Jumlah & $\mathbf{2 0}$ & $\mathbf{1 0 0}$ & $\mathbf{1 0}$ & $\mathbf{1 0 0}$ & $\mathbf{3 0}$ & \\
\hline
\end{tabular}

Dari table 1.6 Terdapat hubungan Factor Pendidikan ibu yang mempengaruhi masalah status gizi (stunting) pada balita $(0.00) p$ value $<0,05$ 
Jurnal Kebidanan Mutiara Mahakam, Vol 8, No 1, Tahun 2020, Hal 51-69

Tabel 1.7 Hubungan Faktor Pendapatan keluarga terhadap Masalah Gizi

(Stunting) pada Balita di Wilayah Kerja Puskesmas Sidomulyo Pekanbaru

Tahun 2019

\begin{tabular}{llcccccc}
\hline No & Uraian & \multicolumn{3}{c}{ Masalah gizi (stunting) } & Jumlah & P value \\
\hline & $\begin{array}{c}\text { Pendapatan } \\
\text { keluarga }\end{array}$ & Ya & $\%$ & Tidak & \% & & \\
\hline 1 & Rendah & 15 & & 5 & & 20 & 0,001 \\
\hline 2 & Tinggi & 5 & & 5 & & 10 & \\
\hline & Jumlah & $\mathbf{2 0}$ & $\mathbf{1 0 0}$ & $\mathbf{1 0}$ & $\mathbf{1 0 0}$ & $\mathbf{3 0}$ & \\
\hline
\end{tabular}

Dari table 1.7 Terdapat hubungan Factor pendapatan keluarga yang mempengaruhi masalah status gizi (stunting) pada balita (0.001) p value $<0,05$

Tabel 1.8 Hubungan Faktor Riwayat Infeksi terhadap Masalah Gizi (Stunting) pada Balita di Wilayah Kerja Puskesmas Sidomulyo Pekanbaru Tahun 2019

\begin{tabular}{cccccccc}
\hline No & Uraian & \multicolumn{3}{c}{ Masalah gizi (stunting) } & Jumlah & P value \\
\hline & $\begin{array}{c}\text { Riwayat } \\
\text { infeksi }\end{array}$ & Ya & \% & Tidak & \% & & \\
\hline 1 & Ada riwayat & 15 & & 8 & & 23 & 0,00 \\
\hline 2 & Tidak ada & 5 & & 2 & & 7 & \\
\hline & Jumlah & $\mathbf{2 0}$ & $\mathbf{1 0 0}$ & $\mathbf{1 0}$ & $\mathbf{1 0 0}$ & $\mathbf{3 0}$ & \\
\hline
\end{tabular}

Dari table 1.8 Terdapat hubungan Factor riwayat penyakit infeksi pada balita yang mempengaruhi masalah status gizi (stunting) pada balita $(0.00) p$ value $<0,05$

Tabel 1.9 Hubungan Faktor Riwayat Imunisasi terhadap Masalah Gizi (Stunting) pada Balita di Wilayah Kerja Puskesmas Sidomulyo Pekanbaru Tahun 2019

\begin{tabular}{llcccccc}
\hline No & Uraian & \multicolumn{4}{c}{ Masalah gizi (stunting) } & Jumlah & P value \\
\hline & $\begin{array}{c}\text { Riwayat } \\
\text { imunisasi }\end{array}$ & Ya & $\%$ & Tidak & \% & & \\
\hline 1 & Lengkap & 6 & 30 & 7 & 70 & 13 & 0,010 \\
\hline 2 & $\begin{array}{l}\text { Tidak } \\
\text { lengkap }\end{array}$ & 14 & 70 & 3 & 30 & 17 & \\
\hline & Jumlah & $\mathbf{2 0}$ & $\mathbf{1 0 0}$ & $\mathbf{1 0}$ & $\mathbf{1 0 0}$ & $\mathbf{3 0}$ & \\
\hline
\end{tabular}

Dari table 1.9 Terdapat hubungan Factor riwayat imunisasi pada balita yang mempengaruhi masalah status gizi (stunting) pada balita (0.010) p value $<0,05$.

Berdasarkan hasil penelitian diketahui bahwa ada 5 faktor yang mempengaruhi terhadap Masalah Gizi (Stunting) pada Balita di Wilayah Kerja 
Jurnal Kebidanan Mutiara Mahakam, Vol 8, No 1, Tahun 2020, Hal 51-69

Puskesmas Sidomulyo Pekanbaru Tahun 2019, Terdapat hubungan Factor pengetahuan ibu yang mempengaruhi masalah gizi (stunting) pada balita (0.00), Terdapat hubungan Factor pendidikan ibu yang mempengaruhi masalah gizi (stunting) pada balita (0.00), Terdapat hubungan Factor pendapatan keluarga yang mempengaruhi masalah gizi (stunting) pada balita (0.001), Terdapat hubungan Factor riwayat penyakit infeksi yang diderita pada balita yang mempengaruhi masalah gizi (stunting) pada balita (0.00), Terdapat hubungan Factor riwayat imunisasi pada balita yang mempengaruhi masalah gizi (stunting) pada balita (0.010).

Ada banyak potensi penyebab stunting (anak kerdil) di Indonesia, termasuk faktor status gizi ibu, praktik pemberian ASI, praktik pemberian makanan tambahan, dan paparan untuk infeksi serta faktor-faktor penentu terkait lainnya seperti pendidikan, sistem pangan, perawatan kesehatan, dan infrastruktur air dan sanitasi dan jasa(Beal et al., 2018), padahal periode emas bagi perkembangan anak sedang terjadi dimana 50\% perkembangan kecerdasan terjadi pada usia 0-4 tahun, 30\% berikutnya hingga usia 8 tahun(Purnomo, 2013).

Pencegahan stunting dapat dilakukan melalui kegiatan yang fokus ditujukan kepada perempuan hamil dan melahirkan, usia sekolah, remaja dan anak-anak muda, dewasa. Anak perlu mengkonsumsi berbagai macam sayuran dan buah-buahan, melakukan monitor rutin pertumbuhan anak di Posyandu (Integrated Service post). Di usia sekolah, dapat dilakukan dengan memeriksa cacing pada semua kelompok umur dan mengajarkan sikap bersih dan lebih sehat dilingkungan sekolah(Setiyabudi, 2019). Disamping itu jika keluarga fokus pada peningkatan gizi pada 1000 hari sejak pembuahan hingga usia 2 tahun pada masa balita sampai remaja tentunya masalah gizi dan stunting dapat diselesaikan dengan baik(McGovern, Krishna, Aguayo, \& Subramanian, 2017)

Pada penelitian ini mayoritas balita laki-laki 17 orang $(56,7 \%)$ mengalami stunting, dan sebagian besar balita berada direntang umur 12-24 bulan sebanyak 11 orang (36,7\%) dan 25-36 bulan sebanyak 12 orang (40\%).

Anak laki-laki berisiko 1,51 kali mengalami stunting. Status gizi pada anak laki-laki digambarkan sebagai "kerapuhan biologis" karena anak lelaki diharapkan 
tingkat pertumbuhannya sedikit lebih cepat dibandingkan dengan anak perempuan dan pertumbuhan mereka mungkin lebih mudah dipengaruhi oleh kekurangan gizi atau paparan penyakit lain(Nshimyiryo et al., 2019).

Berdasarkan umur, balita yang berusia 6-23 bulan berisiko 4,91 kali dan 24 - 59 bulan berisiko 6,34 kali mengalami stunting.Sementara untuk umur, dengan bertambahnya usia anak berhubungan signifikan dengan stunting. Anak berusia 6 hingga 23 bulan berada pada risiko rendah stunting dibandingkan kelompok usia yang lebih tua 24 - 59 bulan, hal ini diduga pemberian ASI eksklusif selama enam bulan pertama yang tinggi dapat memberikan efek perlindungan terhadap stunting pada usia dini, stunting di kalangan anak di bawah 5 tahun diduga akibat pemberian makanan tambahan, jajanan yang tidak baik selama periode penyapihan ketika bayi harus menjalani transisi dari menyusui eksklusif hingga termasuk Makanan pelengkap dalam makanan mereka(Nshimyiryo et al., 2019)

\section{Aspek pengetahuan ibu}

Pengetahuan merupakan hal mendasar yang sangat mempengaruhi ibu dalam melakukan pola asuh dan perawatan balita, kemampuan ibu dalam menstimulasi balita dalam pemenuhan kebutuhan dasar anak: ASUH yaitu kebutuhan terhadap pangan, gizi, perawatan kesehatan anak, pakaian bersih juga rapi, dan kebersihan terhadap lingkungan, ASIH yaitu kebutuhan emosi atau kebutuhan terhadap kasih sayang dari orang tua terhadap anak dan ASAH yang merupakan kebutuhan stimulasi mental bagi anak untuk perkembangan mental psikososial anak. Apabila orang tua sudah baik dalam menstimulasi tumbuh kembang balita, maka orang tua telah memenuhi kebutuhan dasar anak asuh, asih dan asah tersebut(Gobel, 2012)

Keluarga dan orang tua bertanggung jawab dalam mendidik dan mengasuh anak, ini merupakan aspek penting yang harus diperhatikan. Masih adanya perlakuan-perlakuan yang seharusnya tidak didapatkan oleh anak sebagai calon generasi unggul menjadi hal yang sangat disayangkan. Kondisi ini tentunya akan mempengaruhi proses pertumbuhan dan perkembangan balita, diharapakan agar orang tua dan keluarga perlu memiliki pengetahuan dan keterampilan serta kapasitas dalam pengasuhan dan pemberian makan anak(2, 1385). 
Hasil penelitian Septamarini, Nurmasari, Rachma (2019) terlihat bahwa Prevalensi baduta stunting di Kelurahan Bandarharjo 22,6\%. Rerata pengetahuan dan sikap Responsive Feeding (RF) kelompok kasus 59,4\% rendah, 68,7\% kurang sesuai, pada kelompok kontrol 87,5\% cukup, 72,9\% cukup sesuai. Terdapat hubungan antara pengetahuan dan sikap RF dengan kejadian stunting pada baduta usia 6-24 bulan $(\mathrm{p}=0,000 ; \mathrm{OR}=10,2 ; \mathrm{CI}=3,76-27,75) ;(\mathrm{p}=0,003 ; \mathrm{OR}=5,6 ; \mathrm{CI}=2,17-21,67)$, Ibu dengan pengetahuan RF rendah berisiko 10,2 kali lebih besar memiliki anak stunting dibandingkan dengan ibu berpengetahuan cukup. peningkatan pengetahuan terbukti mampu meningkatkan kualitas pemberian makan sehingga menggambarkan bahwa pengetahuan penting dalam menentukan sikap dan perilaku pengasuh dalam pemberian makan(Septamarini, Widyastuti, \& Purwanti, 2019)

Pengetahuan ibu dalam menciptakan generasi emas seharusnya sudah harus ada saat sebelum kehamilan, karena ibu akan berusaha mempersiapkan kehamilannya dengan prilaku hidup sehat, sehingga saat kehamilannya berlangsung asupan nutrisi untuk ibu dan janin sudah sangat terpenuhi(Purnomo, 2013). Jika terjadi kekurangan energi dan protein selama kehamilan akan menimbulkan efek signifikan terhadap pertumbuhan pada janin di dalam rahim yang terlihat dari ukuran panjang tubuh bayi saat lahir nantinya, pemenuhan asupan nutrisi yang tidak adekuat dalam bentuk makro dan mikro nutrisi selama pertumbuhan dan perkembangan sejak rahim memberikan dampak yang sangat signifikan pada kejadian stunting. Pendidikan ibu adalah salah satu indikator pencapaian kesehatan anak serta pemenuhan gizi anak(Indriyan, DewI, \& Salimo, 2018)

Pengetahuan sangat erat kaitannya dengan pendidikan dimana diharapkan seseorang dengan pendidikan tinggi, maka semakin luas pula pengetahuannya. Namun perlu ditegaskan bahwa seorang yang berpendidikan rendah tidak berarti berpengetahuan rendah pula. Peningkatan pengetahuan bukan hanya melalui pendidikan formal, akan tetapi juga dapat diperoleh pada pendidikan non formal.(Gobel, 2012)

Pada penelitian ini dari 30 responden terdapat 16 orang ibu balita memiliki pengetahuan yang kurang tentang stunting, menurut peneliti hal ini sangat berpengaruh terhadap balita mereka yang dapat dilihat 20 diantara balita yang 
dijadikan sampel penelitian mengalami stunting dengan kategori pendek dan sangat pendek. Pada data jelas bahwa banyak dari responden (>50\%) menjawab salah pertanyaan kuesionernya, mereka belum faham tentang pengertian, klasifikasi dan pencegahan dari masalah status gizi, penyebab stunting dan penanganan stunting. Hal ini peneliti duga dari hasil wawancara akibat kurangnya akses informasi responden tentang stunting dari tenaga kesehatan, jika anak mereka sakit responden baru membawa anak mereka kepuskesmas, disamping itu responden juga jarang membawa balita ke posyandu atau puskesmas dengan alasan anak mereka tidak ada jadwal imunisasi lagi.

\section{Aspek Pendidikan ibu}

Pendidikan seseorang akan mempengaruhi proses belajar, semakin tinggi pendidikan seorang makin mudah orang tersebut untuk menerima informasi. Dengan pendidikan tinggi maka seseorang akan cenderung untuk mendapatkan informasi, baik orang lain maupun media massa. Semakin banyak informasi yang masuk semakin banyak pula pengetahuan yang didapat(Gobel, 2012)

Faktor pendidikan orang tua dalam menstimulasi tumbuh kembang balita akan berdampak dan memberikan efek yang berbeda terhadap cara menstimulasi tumbuh kembang balita(Pratama, 2017) Dimana tingkat pendidikan orangtua yang rendah 1,5 kali kemungkinan anak mengalami status gizi kurang dibandingkan ibu pendidikan lebih tinggi demikian juga sebaliknya(R. Handayani, 2017). Dalam beberapa penelitian terdahulu juga menyatakan bahwa pendidikan ibu yang rendah sangat terkait dengan kejadian stunting pada anak. Peluang stunting sekitar dua kali lebih tinggi untuk anak-anak dari orang tua dengan pendidikan terendah dibandingkan dengan yang tertinggi(Beal et al., 2018). Pemenuhan makro dan mikro nutrisi pada balita berhubungan erat dengan pendidikan orangtua, dimana Pendidikan ibu adalah salah satu indikator terkuat dalam mencapai kesehatan anak serta pemenuhan gizi anak. (Indriyan et al., 2018)

Hasil penelitian Anindita (2018) tentang Hubungan Tingkat Pendidikan Ibu, Pendapatan Keluarga, Kecukupan Protein \& Zinc Dengan Stunting (Pendek) Pada Balita Usia 6 - 35 Bulan Di Kecamatan Tembalang Kota Semarang menunjukkan lebih dari separuh ibu $(69,7 \%)$ minimal telah menempuh jenjang SMA (pendidikan 
menengah), sebagian besar keluarga $(60,6 \%)$ berpendapatan di atas UMR Kota Semarang, tidak ada hubungan antara tingkat pendidikan ibu $(\mathrm{p}=0,646)$ dan pendapatan keluarga $(\mathrm{p}=1,000)$ dengan stunting pada balita

Hal ini sangat berbeda dengan hasil penelitian yang sudah peneliti lakukan, dimana tingkat pendidikan ibu yang rendah yaitu 19 responden berhubungan dengan terjadinya stunting pada balita mereka $(0.00<p$ value 0.05$)$, hal ini dikarenakan mayoritas level pendidikan mereka rendah hanya SD, SMP, dikuatkan dari hasil wawancara dan hasil kuesioner responden banyak salah dan mereka tidak faham/tidak mengetahui bagaimana tatalaksana perawatan balita dan bagaimana pentingnya stimulasi pertumbuhan balita mereka.

Disamping itu menurut peneliti yang harus difahami adalah Rendahnya tingkat pendidikan pada keluarga khususnya ibu, memberikan suatu gambaran adanya keterbatasan sumber daya manusia yang akan memberi dampak dalam mengakses pengetahuan khususnya di bidang kesehatan untuk penerapan dalam kehidupan keluarga terutama pada pengasuhan anak Balita. Orang tua dengan pendidikan terakhir SMA,D3,S1 cara menstimulasi tumbuh kembang balita tentunya jauh berbeda dengan orang tua yang pendidikan terakhirnya SD atau SMP. Hal ini memperlihatkan bahwa jenjang pendidikan orang tua yang berbeda baik rendah maupun tinggi akan menunjukan cara menstimulasi tumbuh kembang balita yang berbeda juga.

\section{Pendapatan keluarga}

Dalam keluarga ibu sangat berperan sangat besar dalam tatalaksana / upaya mengatasi masalah asupan gizi keluarga, mulai dari penyiapan makanan, pemilihan bahan makanan, sampai menu makanan. Ibu yang memiliki status gizi baik saat hamil akan melahirkan anak yang bergizi baik juga. Kemampuan keluarga dalam memenuhi kebutuhan makanan (pangan) baik dalam kuantitas maupun kualitas gizinya akan sangat berpengaruh terhadap status gizi anak. Keluarga dengan penghasilan relatif tetap dan tinggi, kemungkinan mengalami kejadian masalah gizi, berat badan kurang dan stunting akan lebih rendah dibandingkan dengan keluarga yang berpenghasilan tidak tetap ataupun pendapatan rendah(Anindita, 2012), ditambah lagi dengan banyaknya anak, perhatian kepada anak tersebut semakin 
berkurang. Apalagi akan adanya penambahan anggota keluarga baru yang akan lahir, tentunya beban ekonomi akan menjadi sebuah kendala bagi keluarga dalam menyajikan makan yang terbaik bagi anak-anaknya. Hal ini sesuai dengan etiologi timbulnya kwashiorkor, yaitu anak kurang gizi akibat kehadiran sang adik, karena sang adik lebih mendapat perhatian dibandingkan kakaknya, dan apabila sosial ekonomi keluarga tersebut rendah kemungkinan konsumsi makanan menurun dan terbagi kepada anak yang lain. Anak yang tidak diberi AS1 0,7 kali lebih rendah berat badannya dibanding anak yang diberi ASI(R. Handayani, 2017)

\section{Penyakit infeksi}

Kejadian stunting menunjukkan bahwa sebagian besar nutrisi yang dibutuhkan anak tidak memadai dan adanya serangan infeksi berulang pada 1000 hari pertama kehidupan sehingga mengakibatkan hambatan perkembangan (Permatasari \& Sumarmi, 2018)

Infeksi yang disebabkan oleh mikroorganisme bakteri, virus, parasite dan lainnya akan melemahkan system imunitas tubuh balita, hal ini akibat kekurangan gizi dapat menurunkan daya tahan tubuh terhadap infeksi sebagai akibat dari menurunnya kemampuan tubuh untuk memproduksi antibodi. Dengan demikian tingkat imunitas pada anak yang mengalami gangguan gizi akan rendah( $R$. Handayani, 2017) Apabila adanya penyakit infeksi, biasanya nafsu makan anak menjadi rendah, dan adanya gangguan dalam absorpsi zat gizi menyebabkan kebutuhan zat gizi anak semakin tinggi(Lupiana, Ilyas, \& Oktiani, 2018)

Seperti pada kasus penyakit diare yang dialami balita akan meningkatkan risiko stunting pada balita, anak diare dengan gizi kurang akan meningkatkan risiko 2,1 kali lebih tinggi dibandingkan anak yang tidak diare, namun ada beberapa kemungkinan tidak tampaknya pengaruh diare terhadap status gizi anak, seperti daya tahan tubuh anak lebih baik dibandingkan pada saat terkena infeksi lainnya seperti penyakit infeksi (ISPA)(Nshimyiryo et al., 2019) Kekurangan gizi dapat menurunkan daya tahan tubuh terhadap infeksi sebagai akibat dari menurunnya kemampuan tubuh untuk memproduksi antibodi. Dengan demikian tingkat imunitas pada anak yang mengalami gangguan gizi akan rendah(R. Handayani, 2017). 
Jurnal Kebidanan Mutiara Mahakam, Vol 8, No 1, Tahun 2020, Hal 51-69

Hasil penelitian Nshimyiryo, et.al (2019) terdapat kasus balita yang mengalami riwayat penyakit diare 462 orang dan diantaranya terdapat balita stunting sebanyak 207 (45\%). terdapat hubungan riwayat menderita diare dengan terjadinya stunting (0.01) (Nshimyiryo et al., 2019) begitu juga dengan hasil penelitian Berhe, et.al (2019) Kejadian diare berulang pada balita 6-24 bulan mengakibatkan risiko stunting 5,3 kali dibanding yang tidak mengalaminya(Id, Seid, Gebremariam, \& Berhe, 2019)

Begitu juga dengan hasil penelitian Permatasari DF, Sumarmi (2018) diperoleh data bahwa balita stunting lebih banyak yang pernah mengalami penyakit infeksi sebesar 76,50\% dibandingkan dengan balita non stunting sebesar 29,40\%, sedangkan pada balita non stunting lebih banyak yang tidak pernah mengalami penyakit infeksi sebesar 70,60\% dibandingkan dengan balita stunting sebesar $23,50 \%$. Balita dengan riwayat pernah mengalami penyakit infeksi berisiko mengalami stunting 0,13 kali lebih besar daripada balita dengan riwayat tidak pernah mengalami penyakit infeksi, atau sekurang-kurangnya 0,04 kali dan paling besar 0,38 kali lebih berisiko dapat mengalami stunting. Hasil uji statistik Chi-Square bahwa nilai $\mathrm{p}=0,01<(\alpha=0,05)$ yang berarti ada perbedaan yang signifikan riwayat penyakit infeksi antara balita stunting dan non stunting(Permatasari \& Sumarmi, 2018)

Senada dengan penelitian ini, dari 30 balita yang diteliti terdapat 23 balita pernah memiliki riwayat penyakit infeksi; seperti demam, ISPA, diare. Menurut peneliti Balita yang sedang sakit cenderung memiliki nafsu makan yang rendah, sehingga kebutuhan nutrisi bagi tubuh tidak terpenuhi dengan maksimal. Balita yang sering sakit memiliki gangguan metabolisme dalam tubuh sehingga mekanisme pertahanan tubuh menurun yang mengakibatkan balita rentan tehadap penyakit.

\section{Riwayat imunisasi}

Pemberian imunisasi pada anak adalah hal yang sangat penting, karena dapat meningkatkan kekebalan tubuh balita dalam melawan penyakit. Adanya serangan kuman dan mikroorganisme lainnya pada tubuh anak, tidak akan menyebabkan anak mengalami infeksi berat dan lebih cenderung lebih cepat pulihnya dibandingkan anak balita yang tidak diimunisasi(Lupiana et al., 2018). 
Jurnal Kebidanan Mutiara Mahakam, Vol 8, No 1, Tahun 2020, Hal 51-69

Hasil penelitian Setiawan, Machmud, Masrul, (2018) dari 74 sampel penelitiannya terdapat responden yang imunisasi tidak lengkap 4 orang (26,7\%) mengalami stunting, 11 orang $(73,3 \%)$ tidak lengkap tidak mengalami stunting, dan tidak terdapat hubungan kelengkapan imunisasi dengan kejadian stunting pada balita $(1,000)>$ p value 0.05 (Setiawan, Machmud, \& Masrul, 2018).

Hal ini berbeda hasilnya dengan penelitian saat ini, dimana dari 30 responden balita yang tidak lengkap imunisasi adalah 17 orang, dan 14 diantaranya mengalami stunting, terdapat hubungan bermakna ketidak lengkapan imunisasi dengan kejadian stunting $(0.010)<$ pvalue 0.05

Anak disebut sudah mendapat imunisasi lengkap bila sudah mendapatkan semua jenis imunisasi yaitu satu kali HB-0, satu kali BCG, tiga kali DPT-HB, empat kali polio, dan satu kali imunisasi campak. Jadwal imunisasi untuk HB-0, BCG, polio, DPT-HB, dan campak berbeda. Banyak faktor yang menyebabkan balita tidak memiliki status imunisasi lengkap yakni karena ibu lupa sudah berapa kali balitanya diimunisasi, ibu tidak mengetahui jenis imunisasi yang didapatkan karena balita sudah cukup lama diimunisasi, catatan dalam KMS tidak lengkap atau tidak terisi, tidak dapat menunjukkan KMS karena hilang atau tidak disimpan oleh ibu. Ibu juga menganggap bahwa imunisasi tidak penting dan masih beranggapan bahwa balita yang telah diimunisasi biasanya mengalami demam (Lupiana et al., 2018)

Pada penelitian ini diperoleh data tentang kelengkapan imunisasi balita menunjukkan bahwa mayoritas balita Stunting memiliki riwayat imunisasi yang tidak lengkap sebanyak 17 orang (65\%). Berdasarkan hasil wawancara terhadap ibu balita yang tidak lengkap imunisasi balitanya menyatakan alasan tidak mau membawa anak ke posyandu untuk imunisasi karena takut efek demam pada anak dan dilarang oleh suami dan orangtua, disamping itu berdasarkan data tampak bahwa balita yang tidak lengkap imunisasinya adalah dengan latar belakang pendidikan orangtuanya yang rendah (SD dan SMP) (61,3\%), sehingga mereka tidak memahami akan pentingnya imunisasi bagi kesehatan anak mereka. Ketidaktahuan mereka juga didukung oleh lingkungan eksternal yang menyebabkan mereka akhirnya tidak membawa anaknya untuk mendapatkan imunisasi rutin pada umur 0-11 bulan. 


\section{SIMPULAN}

Dari hasil penelitian ini diketahui bahwa Klasifikasi Masalah Gizi pada Balita berdasarkan BB/U mayoritas adalah BB kurang (underweight)19 reponden (63,3\%). Berdasarkan TB/U mayoritas Pendek (stunteed), 14 responden (46,7\%), dan berdasarkan BB/TB mayoritas Gizi Baik (Normal) 17 responden (56,7\%). Terdapat Factor yang mempengaruhi masalah status gizi dan stunting pada anak, dari aspek pengetahuan didapatkan hasil 16 responden (53,3\%) berpengetahuan kurang, mayoritas pendidikan ibu Rendah sebanyak 19 orang (63,3\%), ada riwayat infeksi penyakit sebanyak 23 orang $(76,7 \%)$, dan pendapatan keluarga rendah sebanyak 20 orang $(66,7 \%)$ dan imunisasi yang tidak lengkap sebanyak 17 orang (56,7\%). Adanya hubungan factor pengetahuan ibu dengan masalah gizi (stunting) (0.00), Adanya hubungan factor pendidikan ibu dengan masalah gizi (stunting) (0.00), Adanya hubungan factor pendapatan keluarga dengan masalah gizi (stunting) (0.001), Adanya hubungan factor riwayat infeksi pada balita dengan masalah gizi (stunting) (0.00), Adanya hubungan factor riwayat imunisasi dengan masalah gizi (stunting) (0.010). Diharapkan tenaga kesehatan lebih meningkatkan penyuluhan dan edukasi kepada ibu balita dalam memantau masalah gizi dan pertumbuhan balita di wilayah Puskesmas Sidomulyo Pekanbaru dan kepada ibu-ibu yang memiliki balita juga stunting agar lebih mengawasi dan memperbaiki pola asuh dan pemberian nutrisi pada anaknya

\section{DAFTAR PUSTAKA}

Anindita, (Putri). (2012). Hubungan Tingkat Pendidikan Ibu, Pendapatan Keluarga, Kecukupan Protein \&amp; Zinc dengan Stunting (Pendek) pada Balita Usia 6 $\square$ “ 35 Bulan di Kecamatan Tembalang Kota Semarang. Jurnal Kesehatan Masyarakat Universitas Diponegoro, 1(2), 18764. Retrieved from https://www.neliti.com/publications/18764/hubungan-tingkat-pendidikan-ibupendapatan-keluarga-kecukupan-protein-zinc-denga

Bardosono, S. (2016). Penilaian Status Gizi Balita ( Antropometri ). Fakultas Kedokteran UI.

Beal, T., Tumilowicz, A., Sutrisna, A., Izwardy, D., \& Neufeld, L. M. (2018). A review of child stunting determinants in Indonesia. Maternal and Child Nutrition, 14(4), 1-10. https://doi.org/10.1111/mcn.12617 
Boucot, A., \& Poinar Jr., G. (2010). Stunting. Fossil Behavior Compendium, 5, $243-$ 243. https://doi.org/10.1201/9781439810590-c34

Ditjen Kesmas, K. R. (2018). Pedoman Strategi Komunikasi; Perubahan Perilaku dalam Percepatan Pencegahan Stunting di Indonesia. 80. Retrieved from http://kesmas.kemkes.go.id/assets/upload/dir_519d41d8cd98f00/files/Pedoman_ strakom_pencegahan_stunting_1339.pdf

Gobel, H. Van. (2012). Hubungan Pengetahuan Dengan Peran Ibu Dalam Perkembangan Motorik Kasar Bayi Usia 6-9 Bulan Di Posyandu Kelurahan Libuo Tahun 2012. Retrieved from http://download.portalgaruda.org/article.php?article=137465\&val=3587

Handayani, D. S., Sulastri, A., Mariha, T., \& Nurhaeni, N. (2017). Penyimpangan Tumbuh Kembang Anak dengan Orang Tua Bekerja. Jurnal Keperawatan Indonesia, 20(1), 48-55. https://doi.org/10.7454/jki.v20i1.439

Handayani, R. (2017). Faktor-Faktor Yang Berhubungan Dengan Status Gizi Pada $\begin{array}{lllll}\text { Anak Balita. Jurnal } & 217 .\end{array}$ https://doi.org/10.22216/jen.v2i2.1742

Id, K. B., Seid, O., Gebremariam, Y., \& Berhe, A. (2019). Risk factors of stunting ( chronic undernutrition) of children aged 6 to 24 months in Mekelle City, Tigray Region, North Ethiopia : An unmatched case-control study. 1-11.

Indriani, D., Dewi, Y. L. R., Murti, B., \& Qadrijati, I. (2018). Prenatal Factors Associated with the Risk of Stunting: A Multilevel Analysis Evidence from Nganjuk, East Java. Journal of Maternal and Child Health, 03(04), 294-300. https://doi.org/10.26911/thejmch.2018.03.04.07

Indriyan, E., DewI, Y. L. R., \& Salimo, H. (2018). Biopsychosocial Determinants of Stunting in Children Under Five: A Path Analysis Evidence from the Border Area West Kalimantan. Journal of Maternal and Child Health, 03(02), 146155. https://doi.org/10.26911/thejmch.2018.03.02.07

Jahari, A. B. (2018). Reduce Child Stunting Issue. Depkes.Go.Id, 6-8. Retrieved from http://www.depkes.go.id/resources/download/info-terkini/materi pra rakerkesnas 2018/Pakar Stunting.pdf

Kementerian Desa Pembangunan Daerah Tertinggal dan Transmigrasi. (2017). Buku saku desa dalam penanganan stunting. Buku Saku Desa Dalam Penanganan Stunting, 42.

Kementerian kesehatan Repubelik Indonesia. (2018). Data dan Informasi profil Kesehatan Indonesia 2018.

Kementerian Kesehatan RI. (2018). Buku saku pemantauan status gizi. Buku Saku 
Jurnal Kebidanan Mutiara Mahakam, Vol 8, No 1, Tahun 2020, Hal 51-69

Pemantauan Status Gizi Tahun 2017, 7-11.

Kementrian Kesehatan. (2010). Standar Antropometri Penilaian Status Gizi Anak. Standar Antropometri Penilaian Status Gizi Anak, p. 40.

Keuangan, K. (2018). Kementerian Keuangan Penanganan Stunting Terpadu Tahun 2018. https://doi.org/10.1016/j.fct.2017.10.033

Leroy, J. L., \& Frongillo, E. A. (2019). Perspective: What Does Stunting Really Mean? A Critical Review of the Evidence. Advances in Nutrition, 10(2), 196204. https://doi.org/10.1093/advances/nmy101

Lupiana, M., Ilyas, H., \& Oktiani, K. (2018). Hubungan Status Imunisasi, Pendidikan Ibu, Sikap Ibu Dan Pendapatan Keluarga Dengan Status Gizi Balita Di Kelurahan Beringin Jaya Kecamatan Kemiling Kota Bandar Lampung. Holistik Jurnal Kesehatan, 12(3), 146-153.

Manggala, A. K., Wiswa, K., Kenwa, M., Me, M., Kenwa, L., Agung, A., ... Sawitri, S. (2018). Paediatrica Indonesiana. 58(5), 205-212.

McGovern, M. E., Krishna, A., Aguayo, V. M., \& Subramanian, S. V. (2017). A review of the evidence linking child stunting to economic outcomes. International Journal of Epidemiology, 46(4), 1171-1191. https://doi.org/10.1093/ije/dyx017

Nshimyiryo, A., Hedt-gauthier, B., Mutaganzwa, C., Kirk, C. M., Beck, K., Ndayisaba, A., ... El-khatib, Z. (2019). Risk factors for stunting among children under five years : a cross-sectional population-based study in Rwanda using the 2015 Demographic and Health Survey. 1-10.

Permatasari, D. F., \& Sumarmi, S. (2018). Differences of Born Body Length, History of Infectious Diseases, and Development between Stunting and Non-Stunting $\begin{array}{lllll}\text { Toddlers. Jurnal Berkala Epidemiologi, } & 6(2), & 182 .\end{array}$ https://doi.org/10.20473/jbe.v6i22018.182-191

Pratama, D. (2017). Dampak Partisipasi Orang Tua Dalam Kegiatan Bina Keluarga Balita Terhadap Proses Stimulasi Tumbuh Kembang Balita (Studi pada Keluarga Peserta BKB Flamboyan Rw 03 Kelurahan Cigugur Tengah Kecamatan Cimahi Tengah). Jurnal Pendidikan Luar Sekolah, 13(2), 42-52.

Purnomo, H. (2013). Peran Orang Tua dalam Optimalisasi Tumbuh Kembang Anak untuk Membangun Karakter Anak Usia Dini. Prosiding Seminar Nasional Parenting, 34-47.

Sandra, F., Ahmad, S., \& Arinda, V. (2018). Cegah Stunting itu Penting. Warta Kesmas, 1-27. 
Jurnal Kebidanan Mutiara Mahakam, Vol 8, No 1, Tahun 2020, Hal 51-69

Septamarini, R. G., Widyastuti, N., \& Purwanti, R. (2019). Hubungan Pengetahuan Dan Sikap Responsive Feeding Dengan Kejadian Stunting Pada Baduta Usia 624 Bulan Di Wilayah Kerja Puskesmas Bandarharjo, Semarang. Journal of Nutrition College, 8(1), 9. https://doi.org/10.14710/jnc.v8i1.23808

Setiawan, E., Machmud, R., \& Masrul, M. (2018). Faktor-Faktor yang Berhubungan dengan Kejadian Stunting pada Anak Usia 24-59 Bulan di Wilayah Kerja Puskesmas Andalas Kecamatan Padang Timur Kota Padang Tahun 2018. Jurnal Kesehatan Andalas, 7(2), 275. https://doi.org/10.25077/jka.v7.i2.p275-284.2018

Setiyabudi, R. (2019). Stunting, risk factor, effect and prevention. Medisains, 17(2), 24. https://doi.org/10.30595/medisains.v17i2.5656

Smith Fawzi, M. C., Andrews, K. G., Fink, G., Danaei, G., McCoy, D. C., Sudfeld, C. R., ... Fawzi, W. W. (2019). Lifetime economic impact of the burden of childhood stunting attributable to maternal psychosocial risk factors in 137 low/middle-income countries. BMJ Global Health, 4(1), 1-11. https://doi.org/10.1136/bmjgh-2018-001144

Vilcins, D., Sly, P. D., \& Jagals, P. (2018). Environmental risk factors associated with child stunting: A systematic review of the literature. Annals of Global Health, 84(4), 551-562. https://doi.org/10.29024/aogh.2361

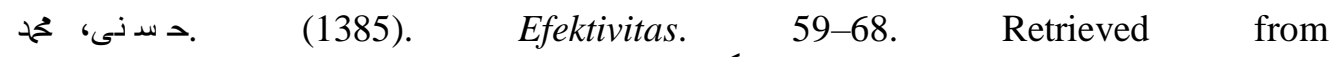

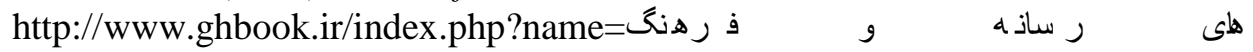
ذو وي ن\&option=com_dbook\&task=readonline\&book_id=13650\&page=73\&chkh ashk=ED9C9491B4\&Itemid=218\&lang=fa\&tmpl=component 